\title{
Chapter 12 \\ Migrant Cosmopolitanism in Emirati and Saudi Cities: Practices and Belonging in Exclusionary Contexts
}

\author{
Hélène Thiollet and Laure Assaf
}

\subsection{Introduction}

Since the beginning of the oil era, the Gulf Cooperation Council (GCC) countries, have experienced a massive increase in regional and international immigration, which translated into some of the highest ratio of foreign residents worldwide. Arab, Asian and European migrants have brought their skills but also their social, gender, cultural, religious and political identities to sparsely populated countries like Qatar, Kuwait and the United Arab Emirates (UAE) and to larger societies like Oman and Saudi Arabia. In Qatar and the UAE, migrants have come to represent up to $90 \%$ of the population and $98 \%$ of the workforce. At the same time, the legal and political context of the Gulf severely limits the formal incorporation of these foreign residents within host societies. In all GCC countries, citizenship regimes are based on ethnicity and autochthony; in practice, access to citizenship was prevented or heavily restricted from the late 1970s on (Beaugrand 2018; Khalaf et al. 2014; Partrick 2012; Okruhlik 1999; Vora 2013). Regardless of the duration of their residence, foreigners are considered to be "temporary labor" and kept "in check" (Longva 1999) through both formal regulations and informal or semi-formal practices which enforce exclusion and segmentation. Among them, the system of sponsorship

This chapter draws upon research published by the authors as "Cosmopolitanism in exclusionary contexts" in Population Space and Place. 2020; e2358. https://doi.org/10.1002/psp.2358

H. Thiollet $(\bowtie)$

CNRS CERI, Sciences Po, IC Migrations, Paris, France

e-mail: helene.thiollet@ sciencespo.fr

L. Assaf

Université Paris Ouest Nanterre, Nanterre, France

NYU Abu Dhabi, Abu Dhabi, United Arab Emirates

(C) The Author(s) 2021

C. Lejeune et al. (eds.), Migration, Urbanity and Cosmopolitanism in a

Globalized World, IMISCOE Research Series,

https://doi.org/10.1007/978-3-030-67365-9_12 
named kafâla binds each migrant worker to a citizen kafil (sponsor), who is usually the employer.

In the 2000s, migration policies have changed. On the one hand, in parallel with a new "migration boom" in the region in the early 2000s, migration policies have become geared towards heavier control and discrimination (Thiollet 2019). In the wake of the 2011 Arab uprisings and, more recently, the diplomatic conflict between Saudi Arabia and the UAE and Qatar as well as the war in Yemen, Gulf monarchies have turned to more repressive modes of governance, which go together with a tighter grip on migration flows (Lori 2019; Thiollet 2015). On the other hand, the diversification of oil economies has boosted Gulf countries' ambitions to secure high-profile membership in the international community through the organization of mega events in the sectors of sports and culture, economic investments abroad, military intervention and cooperation, and humanitarian aid. At the same time as it developed global tourism, the UAE has targeted highly skilled immigrants by offering "golden visas" or relatively long-term residence to real-estate investors, businesspeople and "innovators."

While enforcing more stringently exclusionary policies towards lower- and middle-class migrants, countries like the UAE and Saudi Arabia have thus framed the diversity of their populations within an official rhetoric that lays claim to the countries' cosmopolitanism and openness to the world. ${ }^{2}$ In Saudi Arabia, diversity is often framed as part and parcel of Islamic universalism, linked to Islamic pilgrimages and the mobility of pilgrims within and to Mecca and Medina. ${ }^{3}$ In the UAE, diversity is framed as a marketable asset within processes of city-branding - a form of "commodified cosmopolitanism" (Assaf 2017b). ${ }^{4}$ More recently, the cosmopolitan theme has been reshaped into a national project around the notion of tolerance - portraying the UAE as a beacon of peaceful coexistence in the Muslim world (Thiollet and Assaf 2018). These discourses have concrete effects on migrants

\footnotetext{
${ }^{1}$ Gulf governments seek to maintain high immigration in order to sustain their labor markets (Khalaf et al. 2014). Such discriminatory practices are aligned with the "global race for talents" (Shachar 2006) in liberal democracies, widening inequalities between migrants and citizens but also between migrants, creating hierarchical differences in residence and citizenship based on class, ethnicity, religion and gender (Mau 2010; Thiollet 2019).

${ }^{2}$ It has to be noted that in other Gulf countries, the turn towards economic diversification has been accompanied by a very different rhetoric. Kuwait, for example, has witnessed a rise in xenophobic discourses, including among prominent MPs, which resulted in further exclusionary politics towards all foreign residents.

${ }^{3}$ Both pilgrimages - Hajj, happening every year during one specific month, and the Umrah, or small pilgrimage, which can happen any time - involve unparalleled internal, international and domestic mass mobility: for the 2019 Hajj, 1.8 million Muslims came to Saudi Arabia during the month of Ramadan and more than half of the 600,000 "internal" pilgrims came from all over the kingdom. The 2018 Umrah attracted 11.5 million internal pilgrims and 6.7 million external ones, according to the General Authority for Statistics for Hajj.

${ }^{4}$ See the chapter by Pagès el Karoui in this book for another detailed analysis of cosmopolitanism as commodification in Dubai.
} 
and non-migrants as they inform policies and thus affect everyday lives, producing contradictory beliefs and aspirations, behaviors, and informal or self-regulations.

In this context, talking about cosmopolitanism in the Gulf can sound like a contradiction. Beyond diversity, scholarly definitions of cosmopolitanism are usually loaded with normative expectations that appear at odds with the Gulf's "exclusionary contexts" (Parreñas et al. 2018; Pilati 2016). In this chapter, we argue that cosmopolitan encounters observed in Emirati and Saudi cities embody much broader tensions at work in contemporary cosmopolitan situations - tensions between hierarchies and sympathies, exclusion and incorporation, segregation and circulation, conflicts and transactions, structural constraints and local emancipation.

This article fits in recent debates around subaltern or "working-class" (Werbner 1999) or "discrepant" cosmopolitanism (Clifford 1992) that have promoted a less normative approach to cosmopolitan conditions, understood as the default condition of the majority of the world population in a global era (Beck 2006). The Gulf urban contexts, marked both by their "superdiverse" populations (Vertovec 2007) and their exclusionary politics, constitute a valuable lens to explore the paradoxical condition of cast out, discarded, and rejected cosmopolitans (De Genova and Peutz 2010). Although the scholarly literature and activist expertise on migration in the Gulf often denounces illiberal policies and the mis-treatment of migrant workers (Gardner et al. 2013; Human Rights Watch 2014), recent works have addressed the alternative and informal forms of belonging developed by foreign residents in these contexts (Assaf 2017a; Beaugrand 2018; Lori 2019; Thiollet 2010; Vora 2013; Walsh 2014).

Building upon this line of research, and in line with discussions on situated, plural, abject and subaltern cosmopolitanisms (Nyers 2003; Schiller and Irving 2015; Zeng 2014), we seek to explore cosmopolitan practices and encounters in the Gulf at the city level. Scholarship in urban studies has brought forward the intense spatial segregation in the major cities of the Gulf region, which reflects the transient and precarious status of many foreign residents (Dresch 2006; Elsheshtawy 2019; Khalaf 2006). Segregation operates between citizens and non-citizens, but also across the category of citizens and among immigrant communities along the lines of class, gender, and ethnicity. At the same time, urban space is where these diverse populations cross paths, meet and sometimes mix. Migrants have been and remain central to Gulf urban development - both as city-builders (in the construction and service sector) and as city-dwellers. In this hyper-urbanized region, observing everyday lives at the city level offers an ideal vantage point to grasp the ambiguities and complexities of immigrants' cosmopolitan practices in segregated contexts. ${ }^{5}$ How does cosmopolitanism operate within the discourses and practices of foreigners? How do cosmopolitan encounters actually happen in segregated urban environments? Furthermore, what does the Gulf tell us about the contradictions and paradoxes of cosmopolitanism in general?

\footnotetext{
${ }^{5}$ Cities contain about $88 \%$ of the population in Saudi Arabia and $86 \%$ in the Emirates.
} 
We use ethnographic evidence collected at the city level to show how everyday encounters and interactions between city-dwellers display individual and collective dispositions for diversity. Through a comparison between Riyadh and Jeddah in Saudi Arabia and Abu Dhabi in the United Arab Emirates, we look at internal tensions produced by cosmopolitan situations in Gulf contexts. We first explore the ambivalence of self-presentation in public spaces, through the example of dress codes. While the injunction for citizens to wear the "national dress" in public can appear as an extension of the spatial segregation between citizens and non-citizens, we show how city-dwellers may also use dress codes to circumvent established boundaries between citizens and foreigners, as well as between genders and ethnic groups. We then focus on the paradoxes of cosmopolitan encounters in segregated urban contexts, exploring social practices and interactions in two emblematic sites of urban diversity: modern marketplaces, such as shopping malls, and streets. Looking at the modes of inclusion and exclusion in these spaces, we argue that they become the sites of a "segregated cosmopolitanism" (Mermier 2015): they allow and even foster encounters with the city's urban diversity, in particular through consumption practices. The spatial boundaries and temporariness of these cosmopolitan interactions is precisely what allows them to take place. At the same time, they cannot be easily dismissed, as they contribute to shape city-dwellers' subjectivities - their tastes, attitudes, and aspirations.

This research draws upon ethnographies and qualitative discourse analysis in three urban contexts: Abu Dhabi, Riyadh and Jeddah. While Dubai is often considered as the epitome of the "super-diverse" city, these three cities display similar levels of diversity. We compare case studies that both converge and diverge at the national and urban scale. The UAE and Saudi Arabia stand at both ends of the GCC demographic spectrum. Saudi Arabia, the largest country with 33.5 million inhabitants, has the largest immigrant population in sheer numbers (around 11 million) but the smallest when considered as a share of the total population (30\%). The UAE (total population 9.4 million) has, along with Qatar, the largest proportion of immigrants in the population ( $89 \%$ ) and thus a relatively small total number of nationals. Both countries enjoy high levels of urbanization: $86.5 \%$ for the UAE and $83.8 \%$ for Saudi Arabia (UNDESA-Population Division 2017).

For the UAE, fieldwork conducted in the capital Abu Dhabi from 2010 to 2016 focused on young Emirati nationals and Arab foreign residents (Egyptians, Lebanese, Palestinian, Jordanians, Syrians, Iraqis, Yemenis, and other GCC nationalities) who grew up in the city. For Saudi Arabia, fieldwork was conducted in Riyadh and Jeddah (2006, 2013-2015) on Eritrean, Sudanese, Ethiopian, Yemeni and Pakistani immigrants. We rely on both individual and institutional discourses in their contexts and system of references and on the participant observation of social interactions, spaces and practices. 


\subsection{Residential Segregations, Dress Codes and Cosmopolitan Modes of Identification}

In spite of national and local variations, residential segregation is a structuring feature of Gulf cities since nationals receive land and/or housing that tends to confine them to specific districts. While poorer migrants - who live in labor camps outside the city's limits or, in the case of domestic workers, in their employers' homes - are excluded from access to urban space, wealthy expatriates generally live in exclusive gated communities. But for the intermediate classes which comprise the majority of the population, the diverse populations inhabiting the urban space constitute an important dimension of daily life. This is true even if spatial configurations and urban settings can vary, as exemplified by our two case studies.

In Saudi Arabia, middle-class migrants tend to live in multicultural neighborhoods close to city centers or in medium-income suburban areas. Low-income migrants live in peripheral areas of informal urban growth. The Saudi situation, however, is not uniform. In the eastern oil-town, urbanization is spatially segregated (Seccombe and Lawless 1986) while Riyadh has both impoverished neighborhoods in the city center and in suburban areas where both migrants and poor nationals reside (Ménoret 2018); and Jeddah displays historical features of cosmopolitan mixing of socio-ethnic groups linked to the mobilities of pilgrims (Yamani 2009). In the UAE, many low-income migrants are relegated to labor camps on the urban outskirts (Gardner et al. 2013), but patterns of segregation vary according to each emirate. While Dubai can be described as an urban sprawl along the Gulf, in Abu Dhabi, the high density of the main island has led to a relative mixing of middleclass and lower middle-class populations in an "emerging global city" (Elsheshtawy 2010). Segregation occurs at a more micro-scale: at the level of districts or even within the same block or building (Dresch 2006; Khalaf 2006). Recent developments, by extending the city towards the neighboring islands and the mainland, have brought about more segregated residential areas according to nationality and social class.

Vernacular dress codes can appear as a prolongation, in public spaces, of the residential segregations described above. But they are also subjected to reinterpretations by foreign residents and locals alike, which question the boundaries between nationals and foreigners. Beyond residence, everyday practices in urban spaces thus offer crucial insights into cosmopolitan encounters. In both countries, status groups are recognizable through specific "regimes of visibility" (Lussault 2013) manifested by differentiated dress codes. "National" dress codes ensure that citizens stand out and do not risk being confused with non-citizens. Even if they might wear "Western" garments in more informal contexts, Saudi or Emirati citizens indeed tend to wear mainstream "national" dress in public and work places: the "abâya (black cloak) and a head cover (of various shapes) for women and the white dress named kandûra (UAE) or thawb (Saudi Arabia), the shmagh (chequered headscarf), the guthra (white scarf), and the 'iqâl (black cord around the scarf) for men. The historical construction of these national dresses across the region closely follows processes of 
nation-building (Akinci 2019; Thiollet 2010). They took on a heightened importance from the 1980s on, along with emerging anxieties among the citizen population regarding the demographic importance of foreigners and their potential impact on local society. Foreign residents are generally not expected to wear national outfits and, in some cases, can face social sanctions for doing. Daily dresses for most of them are thus related to the workplace, following corporate dress codes; other ethnic or national dresses are usually worn on weekends and holidays.

However, the apparent consolidation of the citizens/non-citizens divide through dress codes is subject to many variations and subtle differences which come to undermine, and at times to blur, this very distinction. Gender hierarchies can take precedence over the need for national distinction. This is the case of the female dress code in Saudi Arabia: until 2019, all women were required by law to wear the 'abâya in public spaces. ${ }^{6}$ More subtle differences, however, operated: foreign women would forego wearing a veil while strong variations in fashion among Arab and Muslim foreign women would correspond to positions in a class and race-based hierarchy, among Saudis as well as across nationalities (Le Renard 2014).

To some extent, this common dress code, while constraining, allowed migrant women to blend in. Young Eritrean Christian girls interviewed in Riyadh claimed to wear the veil and sometimes cover their face with a niqab so as to move around in public spaces without being noticed. Far from these diversionary strategies, clothing can also amount to a subversive claim: wearing a proper Saudi outfit is a demonstration of an individual partaking in an Islamic mode of belonging which is framed as strongly "Saudi." During an interview in Riyadh, a young Jeddah-born Pakistani lawyer educated in the United States framed the fact that she was wearing the 'abâya and the veil, speaking perfect Arabic (both dialect and standard) as part of her claim of a strong attachment to Saudi Arabia, Islam and to Jeddah, where her parents still lived and where she grew up. In her discourse, belonging to Jeddah was entrenched with a consciously idealized definition of "Saudi-ness" linked to Islam and a pious life. She notably contrasted Saudi Arabia, where she could wear "her" veil and "her" "abâya, to the USA, where her dress as a religious marker was constantly under attack. She described herself as "completely integrated" yet frustrated with not "being" Saudi. After studying at elite universities in the United States, she "returned home" and expected some sort of recognition. In the interview, she lamented her outsider status while often repeating that she "fitted in" perfectly.

Foreign men in Saudi Arabia also sometimes wear the thawb in specific circumstances or as a carefully negotiated understanding of their belonging. Various factors distinguish foreigners who "can" wear the thawb and those who cannot. An Eritrean immigrant in his late forties wearing the thawb, shmagh and "iqâl was interviewed at his workplace in Jeddah. He had arrived in Saudi Arabia in 1982 and immediately settled in Jeddah and learned Arabic. Considering himself a

\footnotetext{
${ }^{6}$ In Saudi Arabia, the black 'abâya was an official obligation for women in public spaces, migrant and non-migrant alike and in late 2017 coloured 'abâyât started to be tolerated in urban areas. The dress code for women was all together suppressed in 2019 in the context of the country's opening to tourism.
} 
well-integrated citizen of Jeddah, he works as a doorman at a private folklore museum in the city center. His comments on the artifacts exposed in the museum showed his knowledge and fondness for Hijazi folk culture. When asked if he wore the Saudi attire for his work, he responded that it was clearly important to look Saudi but that he also wore the outfit at home. He underlined the closeness of Southwestern Arabian traditions with those of eastern Eritrea and Sudan, claiming that it was only natural that he should fit in and dress like a Hejazi. In Jeddah, other Yemeni, Sudanese and Ethiopian interviewees also confirmed that they regularly wore the thob, especially for Friday prayers at the mosque or when meeting friends in public.

In the UAE, while foreigners wearing the national dress is generally frowned upon, similar practices exist among young adults who attended public schools, where a majority of pupils are Emirati citizens. Many young Arab men met in Abu Dhabi - of Egyptian, Palestinian, Syrian or Iraqi origin - had attended these schools and kept close friendship ties with Emirati classmates. They thus tended to wear the dishdasha in social outings with their Emirati friends, as did young women with the 'abâya when invited to Emirati weddings. Outside of these social settings, however, the majority of the foreign youths tend to adopt dress codes that neutralize the signs of national or ethnic status, such as jeans, t-shirts and sneakers - while following more generational norms of taste and trend. These outfits are also at times adopted by Emirati youths, as a way to blend in with the diverse population of Emirati cities. Many young citizens interviewed in Abu Dhabi explained how they sometimes decided to wear jeans instead of the national dress, and to speak English in public spaces, so that they would escape temporarily the injunctions and norms related to their national status.

These various cases reflect the nuances that already exist within the most visible modes of segregation and the possibility of negotiating belonging according to personal and incidental circumstances linked to various characteristics of the individual migrant but also the duration of presence in the city, cultural capital and social networks.

\subsection{Segregated Cosmopolitanisms in Shopping Malls}

Shopping malls are symbolic of the large-scale projects that illustrate the economic diversification of Gulf economies in the early 2000s. While these spaces have often been studied as icons of modernity standardizing consumer culture and identity (Zukin 1998), an extensive body of scholarship looks at malls as examples of the variety of urban contexts and cultures (Abaza 2001; Assaf and Camelin 2017). We argue here that, by excluding certain categories of the population, shopping malls in the Gulf allow the rest of the residents, migrants and citizens alike, to performs certain forms of "consumer cosmopolitanism" whose practices and meanings go beyond mere consumption (Riefler 2015). Malls thus appear as representative of the specific type of segregated cosmopolitanism at play in the public spaces of Gulf 
cities: our research suggests, indeed, that while shopping malls offer a place where hierarchies of nationality, gender and class are certainly enforced, they also represent venues for cosmopolitan interactions and encounters, either through consumerist practices or simply taking a stroll.

While Gulf urbanism is largely car-oriented with high temperatures especially in the summer, shopping malls constitute in many ways a public space by default. They have often been described as a "semi-public" space (Le Renard 2014) to underline, on the one hand, their private ownership and restricted access enforced by security guards. On the other hand, the variety of possible uses of these places and the heterogeneity of populations who frequent them assimilates them to sociological definitions of urban public space (Sennett 1992).

Access to the mall varies according to perceived categories of customers, and is based on intersectional hierarchies, crossing nationality with age, gender, race, and class. The moral geography of stratified spaces of social interaction also varies across the different days of the week (weekend or working days), hours of the day, and according to specific sites. In particular, whether through explicit selection or implicit exclusion, the access to shopping malls in both countries tends to be restricted for lower-class men. In Saudi Arabia, "bachelors" - migrant men- and young single Saudi men are explicitly barred from entering some shopping smalls on week-ends as groups of young men are perceived as a potential threat to the moral order of the place. A combination of racial and class stigma also often prevents low-skilled workers or dark-skinned male immigrants to access some malls. While such rules can be officially pronounced - like the family restriction on weekends- (on a board with the mall's rules), others rely on perceived class, income and race. Access is thus restricted according to intersectional hierarchies of class, gender and race as well as nationality. As observed during fieldwork in Riyadh and Jeddah, a "well-dressed" Indian couple or family or a group of Filipino women is more likely to enter a mall than a group of young Saudi men dressed in poor quality thawb or Western outfits. In the UAE, while no explicit policy officially bans single men from entering malls, such restrictions are occasionally implemented. In 2009, a few months after Al Bawadi mall opened in Al-Ain, the second largest city in the emirate of Abu Dhabi, access to laborers was prohibited because women visitors complained about "stares." This policy was then justified on the basis that these workers did not wear "appropriate clothing" or display "appropriate behavior" in the mall - they were, for example, sleeping on benches (Al Ghalib 2009; Assaf 2017b). At the same time, shopping malls in the UAE are probably one of the most diverse public spaces - where one can encounter both wealthy patrons buying expensive jewellery in the upscale galleries, middle class families shopping for clothes or groceries, or low-skilled employees such as nannies gathering in the food courts during their day off.

The ordinary practices of mall visitors and their social and cultural consequences can disrupt at times the social and spatial segregations at play in Gulf cities. Indeed, malls in the Gulf cannot simply be considered as places of consumption: regular shopping tends to occur mainly in supermarkets and popular markets (suq sha'bî). 
Malls rather constitute social scenes, where specific lifestyles are performed and embodied by foreigners and nationals alike.

Navigating the malls indeed implies having access to a degree of "cosmopolitan capital" (Abaza 2001; Peterson 2011). In many Gulf cities, the ethnic and national division of labor implies that one needs at least a few words of English to benefit from all the services provided by foreign, and often non-Arabic speaking, employees: this holds true from placing an order in an international coffee shop, moving around in recreational spaces or even getting one's car repaired. This required cosmopolitan capital can thus work as a principle of exclusion for poor laborers for whom it is an additional barrier to access commercial spaces, but also for some citizens, especially those who grew up in more rural areas and did not have access to a good education in English.

Conversely, for those who master the codes and subtleties required to navigate the malls, this cosmopolitan capital becomes the basis of strategies of distinction. Such competence is associated with lifestyles and modes of consumption endowed with a global dimension. The ability to be at ease in these globalized commercial spaces appeared central to the social practices of young adults in the UAE. They took pleasure in exhibiting their familiarity with a café's menu, their ease in ordering in English, and their cosmopolitan tastes. Embodying these consumerist lifestyles was not only a mark of distinction but a way to take part in the commodified cosmopolitanism mentioned before and, in a way, to appropriate the city's global ambitions.

Shopping malls thus host ambivalent experiences of leisure for city-dwellers, between the exclusion of the poorer categories of the population and the inclusion of their visitors in global lifestyles that go beyond the scale of the city. Through real and symbolic social transactions, immigrants appear as part of a modernized consumer society connected to global trends but also deeply local. If malls are broader spaces of encounters on the main streets and arteries of the city where people from various neighborhoods convene, small convenience stores also function as catalysts of social interactions in the urban space. But in the perception of self and others, shopping malls have a particular function as shared "places" conveying a sense of belonging to Gulf modernity (Thiollet 2010).

\subsection{Cosmopolitan Streets: The Moral Geography of Coexistence and Encounters}

While residential segregations tend to be aligned with ethnic communities, streetlevel observations show how ethnic economies and in-group consumption practices are connected to the wider urban crowd and intercultural interactions. The streets of popular neighborhoods in Abu Dhabi, Riyadh or Jeddah show signs of an infinite cultural variety to the onlooker: Indonesian restaurants, Eritrean grocery stores, Chinese hardware, McDonald's and KFC, European clothing stores and Middle 
Eastern supermarket chains. Inexpensive ethnic restaurants (Chinese, Pakistani, Sri Lankan, Filipino and Indian) are ubiquitous, banal and more "familiar" in workingclass neighborhoods than American fast food chains. This landscape reproduces the ethnic diversity of the population. Based on our observations, the consumption practices are not strictly tied to one's identity or the demographic composition of the surrounding area. Beyond ethnic economies and globalized cuisine (like Japanese sushi), citizens and non-citizens in Gulf cities have become familiar with the cuisines of other ethnic groups and daily consume Lebanese, Pakistani or Indian food; in many cases, the availability of these diverse cuisines stirs curiosity for others.

Although Gulf cities with their large, orthogonal avenues are mainly meant for cars, things change as soon as one enters smaller neighborhoods. In Dubai or Abu Dhabi, there is a stark contrast between the main roads with up to eight lanes of speeding traffic and the inside of neighborhood blocks where traffic grinds to a halt behind double-parked cars honking in front of a shawarma shop as children play cricket in the parking lot or football on the little square surrounding the local mosque. The experience of the urban neighborhood is often associated with that of the ethnic diversity of urban society. Just like the omnipresent karak (tea with milk) consumed by almost all residents and which has come to be considered an intrinsically "local" drink in the UAE despite its South Asian origin, neighborhood blocks are bustling with small shops displaying a diversity of foods and consumer goods from all over the world. Other public spaces across Abu Dhabi display similar forms of gathering, while maintaining a separation between the groups: several communities gather, cross paths or coexist without necessarily mixing (Elsheshtawy 2019). At dawn or at dusk, the ethnographer taking a stroll on the Abu Dhabi corniche or along the Al-Bateen beach can cross paths with joggers who take advantage of the fresher temperatures. They span many different age categories (between 20 and 50-years old), social classes (unlike gyms, which tend to be separated according to income), and nationalities (from North American to South Asian, Middle Eastern or European) (Assaf 2013a). The end of afternoon is also a time when picnickers start gathering along the corniche or in the public parks. Multi-generational groups of mostly Arab women meet around tea, coffee and biscuits prepared at home while young children are left to play in the playgrounds. Later on, families settle on the grass for elaborate picnics which include barbecues and narghiles. On weekends, these picnics, which in Abu Dhabi are mainly characteristic of the ahl al-shâm, the Levantine families, often take place next to groups of Filipino friends celebrating a birthday party or other families strolling around. While these gatherings maintain a separation between the different groups, they can be considered as "intimacies in the open air" (Assaf 2013b), with each family creating its own space delimited by symbolic rather than physical boundaries. The spectacle of urban diversity thus becomes an integral part of the attraction of these spaces.

Similar distinctions can be observed in neighborhood blocks in Saudi Arabia, notably in middle and working-class neighborhoods of Um al Hamam or Ma'ather in central Riyadh where Saudis mix with various communities of migrants. Jeddah's city center (Al Balad), labelled a World Heritage site by UNESCO in 2014, is surrounded by unplanned settlements hosting middle and working-class populations of 
Saudi internal migrants and foreign residents from extremely diverse backgrounds, with a large Yemeni community. In Jeddah, the corniche is also a site of social encounters. Families walk after dinner on Thursdays and Fridays: kin groups or friends from middle-class migrant and non-migrant backgrounds stride the corniche eating ice creams or sweets. In Riyadh, wealthier migrant families and groups take weekend outings to historical sites and picnics in the nearby desert, whereas working class migrants remain confined to their neighborhoods.

Leisure time spent in these more informal, daily spaces is cosmopolitan by nature, in the sense that it brings together the various communities which compose these urban societies while maintaining boundaries between them. Just like in shopping malls, in this case, the commonality between urban users is located at the very local scale. Incidentally, this is also the scale that is most threatened by recent urban development aiming to create more enclaves and segregation (Elsheshtawy 2019). Constraints upon these practices can be enforced by the municipal police (baladiyya) and certainly there is some degree of social control within migrant communities and across groups. In the UAE, some of the parks and most public beaches now have a paying access, and for some of them are reserved to "families", thus excluding lower-class foreign men who have migrated alone. In Saudi Arabia, gender segregation is strictly enforced notably due to the looming presence of the religious police: the mutawwa'in of the hay'a ("committee" in Arabic, the colloquial term for the religious police, the Committee for the Promotion of Virtue and Prevention of Vice). The hay'a was empowered during a conservative turn in the 1980s and staffed with men armed with a stick who had the power to police the streets for a wide range of minor infractions. In 2016, they lost their right to directly intervene in public spaces, and new decency laws passed in 2019 transferring their policing role to public authorities. But until 2016, the hay'a functioned as a "moral militia" in urban spaces constraining individual and collective behaviors in a gendered, age-sensitive and, to a certain extent, ethnic-based way. Young girls would not dare sit outside of the "family section" of coffee places and restaurants, and young men would not dare enter the family section. This moral policing applied to both Saudi and non-Saudi youth and enforced a gendered and racialized moral urban geography. The risk of being "caught" was far greater for migrants, as it went along with the risk of deportation.

\subsection{Conclusion}

Since the 2000s, while cosmopolitan claims made their way into official rhetoric and diplomacy, Saudi Arabia and the UAE paradoxically adopted more restrictive immigration policies. In Saudi Arabia, brutal controls and mass deportations occurred (Thiollet 2019). In the UAE, policies have favored highly skilled Western migrants while many long-term foreign residents find their visas not renewed for both political and economic reasons. In both countries, increasingly securitized modes of urban governance (Lori 2011) have made communities and daily lives 
more fragile for the low-skilled working classes. While laws preventing the longterm settlement of immigrants are more strictly enforced, wealthier expatriates get access to long-term residency rights, mimicking the global divide in access to residency that can be seen in Western contexts (Shachar and Hirschl 2014).

Cosmopolitanism in denial and the paradoxes of cosmopolitan practices observed in Gulf cities are distinct from mainstream understandings of cosmopolitanism in the West as a "willingness to become involved with the Other, and the concern with achieving competence in cultures" (Hannerz 1990, 239). Cosmopolitan moments and places studied in this chapter are more fragile but not intrinsically opposed to those studied in liberal contexts. As Elijah Anderson (2011) observed in the case of a marketplace in Philadelphia, some places offer temporary enclaves for civility in urban contexts otherwise highly segregated according to class, gender and racial hierarchies. These "cosmopolitan canopies" make way for pacified interactions and encounters between groups that are usually defiant of each other, or whose relationships can be marked by conflict and violence in other contexts. Anderson is careful to underline that the cosmopolitan canopy only operates temporarily, for limited moments; and his proposition has been criticized for referring to elite commercial spaces. But these moments of conviviality are an integral part of city-dwellers' experiences, and influence their subjectivities and their aspirations. They seem all the more important to highlight in Gulf cities as research on the Gulf has mostly studied the impact of emigration on sending countries, while the impact of immigration in Gulf contexts needs to be further documented. As such, it can inform broader discussions on migration and diversity as a vector of social change in host countries (Castles 2001; Portes 2010; Vertovec 2007). It finally amounts to mainstreaming the Gulf in the discussion on "varieties of cosmopolitanisms," to borrow a phrase about capitalism (Hall and Soskice 2001), and considering the importance of ongoing changes despite the difficulty of fully capturing them.

\section{References}

Abaza, M. (2001). Shopping malls, consumer culture and the reshaping of public space in Egypt. Theory, Culture and Society, 18(5), 97-122. https://doi.org/10.1177/02632760122051986.

Akinci, I. (2019). Dressing the nation? Symbolizing Emirati national identity and boundaries through national dress. Ethnic and Racial Studies, 1-19. https://doi.org/10.1080/01419870.201 9.1665697.

Al Ghalib E. (2009, July 7). Mall bans labourers on evenings and weekends. The National. https:// www.thenational.ae/uae/mall-bans-labourers-onevenings-and-weekends-1.486880.

Anderson, E. (2011). The cosmopolitan canopy race and civility in everyday life. New York: W.W. Norton \& Company.

Assaf, L. (2013a). Autour d'un café. Sociabilité des jeunes à Abu Dhabi. In Jeunesses arabes (Cahiers libres, pp. 53-62). Paris: La Découverte. https://www.cairn.info/jeunessesarabes\%2D\%2D9782707177155-page-53.htm?contenu=resume

Assaf, L. (2013b). La Corniche d'Abu Dhabi : Espace Public et Intimités à Ciel Ouvert. Chroniques Yéménites, 2. https://doi.org/10.4000/cy.2625. 
Assaf, L. (2017a). Arab youths of Abu Dhabi: Status categories, urban sociability and the shaping of subjectivities in the United Arab Emirates. Paris Ouest Nanterre.

Assaf, L. (2017b). Le Shopping Mall Comme Moment Urbain: Pratiques Citadines et Transformations Des Espaces Marchands Aux Émirats Arabes Unis. Ateliers d'anthropologie, 44. https://doi.org/10.4000/ateliers.10413.

Assaf, L., \& Camelin, S. (2017). Introduction. Ateliers d'anthropologie, 44. https://doi.org/10.4000/ ateliers. 10365 .

Beaugrand, C. (2018). Stateless in the Gulf: Migration, nationality and society in Kuwait. Library of Modern Middle East Studies. I.B.Tauris Publishers.

Beck, U. (2006). The cosmopolitan vision. Cambridge/Malden: Polity.

Castles, S. (2001). Studying social transformation. International Political Science Review/Revue Internationale de Science Politique, 22(1), 13-32.

Clifford, J. (1992). Traveling cultures. In L. Grossberg, C. Nelson, \& P. A. Treichler (Eds.), Cultural studies (pp. 96-116). New York: Routledge.

De Genova, N., \& Peutz, N. M. (Eds.). (2010). The deportation regime: Sovereignty, space, and the freedom of movement. Durham: Duke University Press.

Dresch, P. (2006). Foreign matter: The place of strangers in gulf societies. In J. W. Fox, N. Mourtada-Sabbah, \& M. al-Mutawa (Eds.), Globalization and the Gulf (pp. 200-222). London: Routledge.

Elsheshtawy, Y. (2010). Redrawing boundaries: Dubai, an emerging global city. In Y. Elsheshtawy (Ed.), Planning middle eastern cities: An urban kaleidoscope in a globalizing world (pp. 169-199). New York/London: Routledge/Taylor \& Francis.

Elsheshtawy, Y. (2019). Temporary cities: Resisting transience in Arabia. Milton Park/Abingdon: Routledge.

Gardner, A., Pessoa, S., Diop, A., Al-Ghanim, K., Le Trung, K., \& Harkness, L. (2013). A portrait of low-income migrants in contemporary Qatar. Journal of Arabian Studies, 3(1), 1-17. https:// doi.org/10.1080/21534764.2013.806076.

Hall, P. A., \& Soskice, D. W. (Eds.). (2001). Varieties of capitalism: The institutional foundations of comparative advantage. Oxford/New York: Oxford University Press.

Hannerz, U. (1990). Cosmopolitans and locals in world culture. Theory, Culture and Society, 7(2-3), 237-251. https://doi.org/10.1177/026327690007002014.

Human Rights Watch. (2014). 'I already bought you'. Abuse and exploitation of female migrant domestic workers in the United Arab Emirates. Washington, DC: Human Rights Watch. https://www.hrw.org/report/2014/10/22/i-already-bought-you/ abuse-and-exploitation-female-migrant-domestic-workers-united.

Khalaf, S. (2006). The evolution of the Gulf city type, oil and globalization. In J. W. Fox, N. Mourtada-Sabbah, \& M. al-Mutawa (Eds.), Globalization and the Gulf (pp. 244-265). London: Routledge. https://doi.org/10.4324/9780203965306-23.

Khalaf, A., AlShehabi, O., \& Hanieh, A. (2014). Transit states: Labour, migration and citizenship in the Gulf. London: Pluto Press.

Le Renard, A. (2014). A society of young women: Opportunities of place, power, and reform in Saudi Arabia. Stanford: Stanford University Press.

Longva, A. N. (1999). Keeping migrant workers in check: The Kafala system in the Gulf. Middle East Report, 211. https://merip.org/1999/06/keeping-migrant-workers-in-check/.

Lori, N. (2011). National security and the management of migrant labor: A case study of the United Arab Emirates. Asian and Pacific Migration Journal, 20(3-4), 315-337. https://doi. org/10.1177/011719681102000304.

Lori, N. (2019). Offshore citizens: Permanent temporary status in the Gulf (1st ed.). Cambridge: Cambridge University Press. https://doi.org/10.1017/9781108632560.

Lussault, M. (2013). Visibilité (régime de). In J. Lévy \& M. Lussault (Eds.), In Dictionnaire de la géographie [et de l'espace des sociétés]. Paris: Belin. 
Mau, S. (2010). Mobility citizenship, inequality, and the liberal state: The case of visa policies. International Political Sociology, 4(4), 339-361. https://doi.org/10.1111/j.1749-5687.2010. 00110.x.

Ménoret, P. (2018). Urban sprawl and politics in Saudi Arabia. In E. Woertz \& M. Ajl (Eds.), "Wise cities" in the Mediterranean?: Challenges of urban sustainability (pp. 201-211). Barcelona: CIDOB, Barcelona Centre for International Affairs.

Mermier, F. (2015). Récits de Villes: D'Aden à Beyrouth: Essai. Sindbad. Paris: Actes Sud.

Nyers, P. (2003). Abject cosmopolitanism: The politics of protection in the anti-deportation movement. Third World Quarterly, 24(6), 1069-1093.

Okruhlik, G. (1999). Excluded essentials: The politics of ethnicity, oil and citizenship in Saudi Arabia. In P. Batur-Vanderlippe (Ed.), The global color line: Racial and ethnic inequality and struggle from a global perspective (Research in politics and society 6) (pp. 215-236). Greenwich: JAI Press.

Parreñas, R. S., Silvey, R., Hwang, M. C., \& Choi, C. A. (2018). Serial labor migration: Precarity and itinerancy among Filipino and Indonesian domestic workers. International Migration Review. https://doi.org/10.1177/0197918318804769.

Partrick, N. (2012). Nationalism in the Gulf states. In D. Held \& K. Ulrichsen (Eds.), The transformation of the Gulf: Politics, economics and the global order. Abingdon/New York: Routledge.

Peterson, M. A. (2011). Connected in Cairo: Growing up cosmopolitan in the modern Middle East (Public cultures of the Middle East and North Africa). Bloomington: Indiana University Press.

Pilati, K. (2016). Migrants' political participation in exclusionary contexts: From subcultures to radicalization (Palgrave Pivot). New York: Palgrave Macmillian.

Portes, A. (2010). Migration and social change: Some conceptual reflections. Journal of Ethnic and Migration Studies, 36(10), 1537-1563. https://doi.org/10.1080/1369183X.2010.489370.

Riefler, P. (2015). Consumer cosmopolitanism. In D. T. Cook \& J. M. Ryan (Eds.), The Wiley Blackwell encyclopedia of consumption and consumer studies (pp. 1-2). Oxford: Wiley. https:// doi.org/10.1002/9781118989463.wbeccs247.

Schiller, N. G., \& Irving, A. (2015). Introduction. In N. G. Schiller \& A. Irving (Eds.), Whose cosmopolitanism? Critical perspectives, relationalities and discontents (1st ed., pp. 1-22). New York: Berghahn Books. http://www.jstor.org/stable/j.ctt9qd17s.5.

Seccombe, I. J., \& Lawless, R. (1986). Foreign worker dependence in the Gulf, and the international oil companies: 1910-50. International Migration Review, 20(3), 548. https://doi. org/10.2307/2545704.

Sennett, R. (1992). The conscience of the eye: The design and social life of cities (1. paperback ed.). New York: Norton.

Shachar, A. (2006). The race for talent: Highly skilled migrants and competitive immigration regimes. New York University Law Review, 81(1), 148-233.

Shachar, A., \& Hirschl, R. (2014). On citizenship, states, and markets. Journal of Political Philosophy, 22(2), 231-257. https://doi.org/10.1111/jopp.12034.

Thiollet, H. (2010). Nationalisme d'Etat et nationalisme ordinaire en Arabie Saoudite: la nation saoudienne et ses immigrés [State nationalism and banal nationalism in Saudi Arabia: The Saudi nation and its immigrants]. Raisons politiques, 37(1), 89-101. https://doi.org/10.3917/ rai.037.0089.

Thiollet, H. (2015). Migration et (contre)révolution dans le Golfe: politiques migratoires et politiques de l'emploi en Arabie saoudite [Migration and (counter)revolution in the Gulf. Migration and Labour market policies in Saudi Arabia]. Revue européenne des migrations internationales, 31(3-4), 121-43.

Thiollet, H. (2019). Immigrants, markets, brokers and states. The politics of illiberal migration governance in the Arab Gulf (Working Paper. IMI Working Paper Series). Amsterdam: International Migration Institute.

Thiollet, H., \& Assaf, L. (2018, January 27). Cosmopolitanism in denial. The illiberal politics of migration and everyday diversity in the Gulf cities. Presented at the Symposium "Migration: 
displacement and development in the MENA region, Institute of Arab and Islamic Studies, University of Exeter.

United Nations, Department of Economic and Social Affairs, Population Division. (2017). International migration report 2017. ST/ESA/SER.A/403. New York: United Nations Department of Economic and Social Affairs. http://www.un.org/en/development/desa/population/migration/publications/migrationreport/docs/MigrationReport2017.pdf

Vertovec, S. (2007). Super-diversity and its implications. Ethnic and Racial Studies, 30(6), 1024-1054. https://doi.org/10.1080/01419870701599465.

Vora, N. (2013). Impossible citizens: Dubai's Indian diaspora. Durham/London: Duke University Press.

Walsh, K. (2014). Placing transnational migrants through comparative research: British migrant belonging in five GCC cities: Placing transnational migrants through comparative research. Population, Space and Place, 20(1), 1-17. https://doi.org/10.1002/psp.1798.

Werbner, P. (1999). Global pathways. Working class cosmopolitans and the creation of transnational ethnic worlds. Social Anthropology, 7(1), 17-35. https://doi.org/10.1111/j.14698676.1999.tb00176.x.

Yamani, M. (2009). Cradle of Islam: The Hijaz and the quest for identity in Saudi Arabia. London: I..B.Tauris.

Zeng, M. (2014). Subaltern cosmopolitanism: Concept and approaches. The Sociological Review, 62(1), 137-148. https://doi.org/10.1111/1467-954X.12137.

Zukin, S. (1998). Urban lifestyles: Diversity and standardisation in spaces of consumption. Urban Studies, 35(5-6), 825-839. https://doi.org/10.1080/0042098984574.

Open Access This chapter is licensed under the terms of the Creative Commons Attribution 4.0 International License (http://creativecommons.org/licenses/by/4.0/), which permits use, sharing, adaptation, distribution and reproduction in any medium or format, as long as you give appropriate credit to the original author(s) and the source, provide a link to the Creative Commons license and indicate if changes were made.

The images or other third party material in this chapter are included in the chapter's Creative Commons license, unless indicated otherwise in a credit line to the material. If material is not included in the chapter's Creative Commons license and your intended use is not permitted by statutory regulation or exceeds the permitted use, you will need to obtain permission directly from the copyright holder. 